\title{
Neurosis and Psychosis in German and French Nosography
}

\author{
Ronaldo Chicre Araujo*, José Dionísio de Paula Júnior, Gabriel da Costa Duriguetto and Nathália Corbelli \\ Fernandes
}

Department of Psychology, Foundation President Antônio Carlos (FUPAC), Brazil

Received: 齿 September 17, 2018; Published: 畊 September 20, 2018

*Corresponding author: Ronaldo Chicre Araujo, Department of Psychology, Foundation President Antônio Carlos (FUPAC), Rua Lincoln Rodrigues Costa, Brazil

\section{Opinion}

Neuroses and psychoses refer to clinical and nosographic problems. The terms psychoses and neuroses have long existed in the nosological vocabulary. Initially, they do not constitute a pair of opposites, they do not exclude themselves, they can overlap. Psychosis corresponds to mental illness, the psychiatric condition [1]. It is the technical concept to replace the term madness. In the nineteenth and early twentieth century, psychosis covered both mental disorders of organic origin, for example, "paralytic psychosis" to designate general paralysis, such as functional diseases, ie delusions, as well as some mental disorders, like "obsessive psychosis", which today could be called neurosis. The term neurosis is rather an aetiological and nosological concept, since the disorders are not based on the organic lesion. Psychoses without organic bases and not triggered by a toxic-infectious process could be considered neuroses. In Krafft-Ebing's German nosology we find the characteristic and affective mental disorders of the neurotics called "neuropsychoses"; the psychic crises and the hysterical states that are part of the neurosis; and the psychoses of the neuroses that differed in some details from autonomic psychoses, such as hysterical paranoia. Krafft- Ebing contrasted the mental state of the neurotic with the neurotic-based psychoses. These included mental accidents that were part of the neuroses, such as the delusions of hysterical attacks, and the psychoses in which neurosis served as the basis for the development of a typical psychosis, especially of hysterical paranoia that had visual hallucinations and mystical themes and hypochondriac paranoia, which had in the center of delirium the cenestopaths [2].

The authors of German psychopathology generally depart from a physiological interpretation of the clinical picture. In contrast, French clinical observation relegates physiological considerations to the background. However, this effort of a physiological interpretation of the clinic has its place of importance. At the end of the nineteenth century, Kraepelin imposed a new clinic in Germany, which relies on the classical isolation of acquired psychoses, which have an obvious organic cause, such as toxinfectious states, organic dementias, and degenerative forms in which there is a pathological predisposition personality, such as oligo frenias and neurotic disorders. In 1899, he describes non-hallucinatory systemic chronic delusions. These delusions are part of the pictures of psychosis characterized by permanent delusions. These delusional ideas cannot be conceived as mere errors of judgment [3]. From the nosographic classification of Kraepelin and later on with the works of Bleuler, many of these delusions became part of schizophrenia. Systematic chronic delusions, also called paranoid psychoses, are, in general, very well organized, with rich and consistent histories. They maintain, over time, their contents and the wealth of details [4]. They present a logical construction, from false elements, which are Clérambault's postulates of the delirious fable [5]. Its evolution is insidious and progressive. Their power of conviction is great and may cause others to actively participate in delirium as induced delusions. In the group of chronic delusions systematized are the passionate delusions. Although this delusion often entails a difficult diagnostic problem, it should be noted that these passionate states are generated from a characteristic imbalance. They are accompanied by disorders such as hallucinatory experiences, depersonalization, and impulsivity. In these cases, passion has an essentially imaginary structure [6]. Resuming the German and French nosography makes it possible to describe more accurately the clinical pictures.

\section{References}

1. Berecherie P (2014) Structure des psychoses. Une synthèse postlacanienne. L'Harmattan, Paris.

2. Clerambault G (1942) Les psychoses passionnelles. Oeuvres. Presses Universitaires de France, Paris pp. 311-455. 
3. Clerambault G (1921) Les delires passionnels. Érotomanie, Revendication, Jalousie. (Présentation de malade), Bulletin de la Société Clinique de Médecine Mentale février p. 61.

4. Ey H, Bernard P, Brisset C (1989) Manuel de psychiatrie (6 ${ }^{\text {th }}$ edn.), Masson, Paris, France.
5. Dalgalarrondo P (2000) Psicopatologia e semiologia dos transtornos mentais. Porto Alegre: Artes Médicas.

6. Kraft E, Bing R (1897) Traite Clinique de psychiatre, traduit sur la cinquime edition allemande par le dr. Emile laurent, A Maloine, paris.

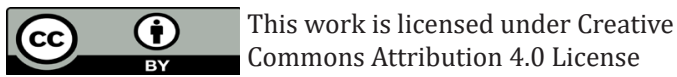

To Submit Your Article Click Here:

Submit Article

DOI: $10.32474 / 0 J N B D .2018 .01 .000125$

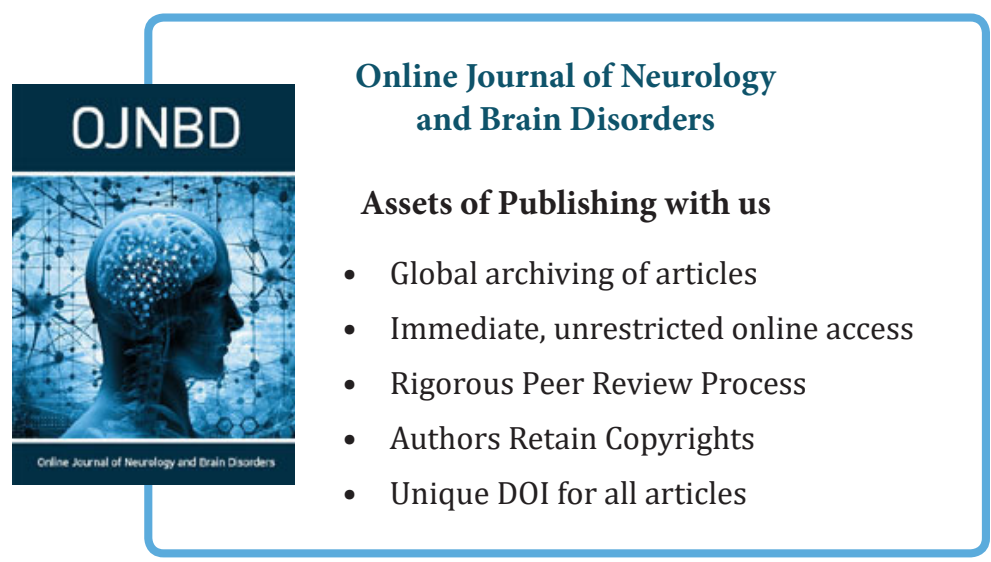

